\title{
The effects of trade sanctions and disinvestment by foreign countries and its impact on the South African economy
}

\author{
N. Bhana \\ Graduate School of Business, University of Durban-Westville, Private Bag X54001, Durban, 4000 Republic of South Africa
}

Accepted 4 June 1987

\begin{abstract}
In the event of total trade sanctions South Africa should have no difficulty in countering the ban on mineral exports, especially precious metals. Furthermore, earnings from precious metals are likely to increase in the short term followed by a gradual deterioration of these industries as cheaper substitutes are developed and producers from other countries make inroads into markets vacated by South African producers. In the manufacturing sector South Africa may benefit in the short term through import replacement and a drive towards self-sufficiency. However, in the long term factors such as scarcity of capital, technological obsolescence, disadvantages inherent in the lack of international co-operation and competition, and misallocation of resources would indicate that the cost of evading sanctions is too high. A disinvestment of portfolio investments is likely to cause a major decline in the prices of South African mining shares. A large scale disinvestment by multinational companies and foreign disinvestment of shares are likely to cause restructuring and increased economic concentration in the South African economy.
\end{abstract}

In dic geval van algehele handelsanksies, behoort Suid-Afrika geen probleme te ondervind om die verbod op minerale uitvoer teen te werk nie, veral betreffende die edelmetale. Bowendien sal die inkomste uit edelmetale waarskynlik toencem in die korttermyn, gevolg deur 'n geleidelike agteruitgang van hierdie industrieë, aangesien goedkoper plaasvervangers ontwikkel word en vervaardigers van ander lande inbreuk maak op markte wat ontruim is deur Suid-Afrikaanse vervaardigers. In die vervaardigingssektor behoort Suid-Afrika in die korttermyn te baat by die voordele van invoervervanging en 'n strewe na selftoereikendheid. Op die langtermyn egter sal faktore soos 'n gebrek aan kapitaal, tegnologiese veroudering, nadele inherent aan die gebrek aan internasionale samewerking en wedywering, en die wantoekenning van bronne, aandui dat die koste van die ontduiking van sanksies te hoog is. 'n Disinvestering van portefeulje-beleggings sal waarskynlik 'n algehele agteruitgang in die pryse van Suid-Afrikaanse mynaandele tot gevolg hê. 'n Grootskaalse disinvestering deur multinasionale maatskappye en buitelandse disinvestering van aandele sal waarskynlik lei tot herstrukturering en 'n toename in ekonomiese toespitsing in die Suid-Afrikaanse ekonomie.

\section{Introduction}

In recent years there has been a growing campaign to withdraw foreign capital from South Africa. The argument of the advocates of disinvestment is that the withdrawal of foreign capital will force the South African government to speed up reform and provide a more equitable political dispensation. Critics of disinvestment argue that the South African government is more likely to advance political reform during periods of economic prosperity and the absence of a threat of economic sanctions. To date, there has been no large scale disinvestment or economic sanctions against South Africa. However, the United States is taking an increasingly active stand against trading with South Africa and could well influence other countries having trade links with this country. Koenderman (1985) has demonstrated that large scale economic sanctions against South Africa have not been effectively implemented because this country is a major supplier of strategically vital minerals to the Western countries. However, in recent years economic sanctions against South Africa have become a major emotional issue for pressure groups such as the AntiApartheid Movement. As a result of this pressure several foreign governments have been obliged to impose some form of economic sanctions against South Africa. Furthermore, companies such as Barclays, Kodak, and Coca-Cola, whose products and services are highly visible have been obliged to disinvest from South Africa in order to escape the continuous barrage from critics of the racial policies of the South African government.

\section{The trade sanctions and disinvestment debate}

Although the disinvestment campaign in the United Kingdom and the European countries is not strong or well organized, it is rapidly gaining momentum in the United States of America. The disinvestment movement started as isolated campus campaigns at certain radical American universities, but has now grown into a national movement which is enjoying the support of a wide spectrum of public opinion. It has been reported (The Economist, 1985a) that various states, cities, universities, labour, and church authorities in the United States have divested themselves of securities held in companies that operate or have subsidiaries in South Africa. It is further reported that American banks have drastically reduced their direct lendings to the public sector in South Africa. Furthermore, the refusal by several major American banks to rollover short-term debt by South African borrowers precipitated a major foreign exchange crisis which led to a four-month moratorium on foreign loans, reimposition of exchange control on non-residents, and the reintroduction of the financial rand that came into effect on 2 September 1985.

Major factors militating against economic sanctions and disinvestment are the political reforms currently taking place in South Africa and the support of conservative governments in countries such as the United 
Kingdom, United States, and West Germany. Nevertheless, South Africa should not become complacent because of the minimal success attained by the disinvestment lobby. Economic pressure against South Africa will abate only if there is immediate and substantial political reform in South Africa which offers tangible proof that the government is sincere in removing all forms of discrimination in this country. Minor political reforms initiated by the government are not likely to satisfy South Africa's overseas critics. In the final analysis overseas critics are likely to abandon economic pressure when all forms of discrimination are removed and a genuinely democratic government is installed in South Africa. This is clearly illustrated by the international isolation of several sporting organizations despite the removal of all forms of discrimination relating to those organizations' sporting activities and facilities. It may be argued that political change has been slow because of the 'constructive engagement' policy adopted by conservative governments in the major industrialized countries. However, the sanctions and disinvestment lobby may gain the upper hand in the event of liberal leaders being elected in countries that exert strong political influence over South Africa.

The politico-economic situation in South Africa has played a major role in the disinvestment campaign against this country. During the 1960s and the 1970s South Africa experienced a period of relative prosperity which resulted in massive inflows of foreign capital to take advantage of the superior investment returns offered in this country. However, by 1983 South Africa was experiencing a severe recession which resulted in substantial declines in profitability. In addition, the political situation in South Africa deteriorated further and this led to a further erosion of overseas confidence regarding their investments in this country. The abolition of exchange control over non-residents in February 1983 provided the necessary stimulus for foreign companies seeking to disinvest from South Africa. A report by JSE brokers (Davis Borkum Hare, 1983) revealed that during the first half of 1983 there was a total disinvestment in the South African economy by foreign investors amounting to R1300 million. Net sales of JSE listed equities amounted to R720 million and the remainder represented the purchase of controlling interest in overseas companies selling out or reducing their investment in South Africa.

It has been reported (The Economist, 1985c) that by June 1985 more than 30 foreign multinational companies had disinvested all or part of their investments in South Africa since the abolition of exchange control over nonresidents in 1983. It was further reported that companies disinvesting South African holdings included many household names such as Coca-Cola, Apple Computers, Helena Rubenstein, International Harvester, and Metal Box. As a result of recent economic sanctions legislation in the United States and the European Economic Community (EEC), the list of foreign multinationals disinvesting from South Africa has increased substantially. During 1986 major United States multinationals such as General Motors, General Electric, IBM and Kodak have decided to disinvest rather than contend with the "hassle factor' of operating in South Africa. Furthermore, several large United Kingdom companies such as Barclays, Prudential, and Hill Samuel have also decided to disinvest completely or reduce their stake in South Africa as a result of pressure from political activist groups. The foreign companies which have disinvested from South Africa represent some of the largest and most influential multinational companies. Northedge (1986) has argued that the anti-South Africa activists overseas will intensify pressure on the remaining group of businesses still maintaining links with South Africa.

Despite the hardening of attitudes in the United States towards investing in South Africa, investors from that country are still showing a strong preference for investing in high quality South African goldmining and mining house shares. It has been reported (The Economist, 1985b) that despite the large investment outflow in 1983, an amount exceeding Rl billion was invested on the JSE by foreign investors in 1984. A large part of this massive investment inflow was by institutional investors and gold/precious metals investment funds from the United States. In the past few years the performance of gold has been poor and gold shares are not attracting much attention from foreign investors. However, foreign in vestors are not selling off their holdings in South African goldmining shares. It would seem that foreign investors are holding on to their goldmining shares in anticipation of a rise in the gold price, a stronger rand and a possible increase in the dollar price of gold shares.

A major development in the disinvestment campaign against South Africa was the selective sanctions package signed by President Reagan in September 1985. In terms of this executive order the following sanctions were imposed against South Africa: a prohibition of bank loans to the South African government; a restriction on the sale of nuclear goods and the sale of computers and computer software to the South African government; and a prohibition on the importation of krugerrands. These sanctions are of limited scope and are unlikely to do any serious damage to the South African economy. Nevertheless, these measures have encouraged the disinvestment lobby to take a more active stand against foreign investments in South Africa.

In response to the United States sanctions package the pro-sanctions lobby within the EEC began advocating selective sanctions against South Africa. Because of disagreements among member countries only a limited package of sanctions was introduced by the EEC countries during their meeting in September 1986. Items included in the embargo list against South Africa are: iron, steel, krugerrands, and new direct investments. The EEC could not reach an agreement on banning coal imports from South Africa and it was resolved to review the position after a period of six months. Shuttleworth (1986a) has shown that the EEC accounts for about $54 \%$ of South Africa's coal exports which were worth nearly $\mathrm{R} 3,2$ billion in 1985 . The possible inclusion of coal into the EEC sanctions package is likely to have a major impact on the South African economy as about 40000 jobs in the coal mining industry could be lost. While the items 
included in the sanctions package are not major foreign exchange earners, the depressed iron and steel industry, already burdened with excess capacity, could face severe hardships if alternative markets cannot be found.

If attempts to secure a total ban on the importation of iron, steel, coal and iron-ore from the markets of the EEC, the United States, Japan and the Commonwealth is successful, a loss of 130000 jobs can be anticipated in South Africa, of which more than 100000 will be black jobs. Active and productive industrial and mining towns such as Newcastle, Middleburg, Witbank, Saldanha Bay and Richards Bay could become derelict towns of neglect and abandon. To this should be considered the impact on electricity sales, transport services and the varying services performed by other parastatals, private and public corporations and we would find that an estimated 300000 jobs could be jeopardized. If one assumes that each economically active employed individual provides comfort and security for a minimum of six other dependents, then the imposition of total trade sanctions will have the potential to affect almost two million individuals. Moral platitudes on the part of foreign governments will not provide compensation to the bearers of the impact of their actions.

A more recent development in the sanctions war against South Africa is the Comprehensive AntiApartheid Act of 1986 which became law in the United States on 3 October 1986 . This Act is substantially more comprehensive than the previous sanctions package brought into existence by president Reagan's executive order in 1985. The latest sanctions package includes a ban on the importation of: uranium, coal, textiles, iron, steel, arms and ammunition, military vehicles, agricultural products and food, krugerrands, and petroleum products. The Act also terminates the landing rights to South African Airways in the United States as well as the termination of the bilateral treaty on avoidance of double taxation. The United States import figures for 1985 suggest that the sanctions package will affect South African exports worth $\mathbf{3 5 0}$ million dollars. The American Chamber of Commerce in South Africa is of the opinion that these sanctions are hardly likely to cause major hardships to South Africa, nevertheless, sanctions will make life more difficult for local exporters.

The Comprehensive Anti-Apartheid Act of 1986 also makes provision for all United States companies operating in South Africa to implement a statutory code of conduct if they have 25 employees or more. Under the new legislation United States companies are also required to register on a presidential list, with the proviso that companies may be precluded from government export aid if they are found to be not adequately implementing the employment codes. United States companies have long been exposed to conforming to employment codes and the like. However, such requirements complicate matters at a time when very few United States companies are operating at a profit in South Africa (Financial Mail, 1986b). Furthermore, many state and municipalities in the United States are following selective procurement policies whereby they refuse to do business with companies operating in South
Africa (Spicer, 1985). It can be argued that as a result of these additional problems, many United States companies have come to realize that it is not to their advantage to operate in South Africa. As a result, there has been a spate of disinvestments by United States companies (General Electric, General Motors, IBM, Kodak, etc.) during 1986. It has been shown that recent disinvestments has resulted in direct United States investment in South Africa of about 2,6 billion dollars in 1984 to be reduced to approximately 1,3 billion dollars at the beginning of $1986^{1}$.

\section{The effects of trade sanctions on the South African oconomy}

Spandau (1979) analyzed the social, political, and economic consequences of a possible trade boycott against South Africa. Spandau (1979) showed that, in the early stages of an economic boycott the South African economy will actually be stimulated by import replacement and a drive towards self-sufficiency. However, in the long term, the lack of essential ingredients such as foreign competition; technology; foreign capital, management and other skilled resources will have a detrimental effect on the economy. Therefore, in the long term the profitability of South African companies can be expected to decline as the full impact of the trade boycott is felt by the South African economy. This analysis suggests that a programme of securities disinvestment combined with a trade boycott is likely to stimulate share prices on the stock exchange in the short term, but will have a depressing effect on security prices as the inefficiencies and scarcities filter through the economy.

Malan (1981) has shown that despite the programme of import substitution the dependence of South Africa on foreign trade and capital has not decreased. It was further shown that foreign investment assumes added significance because of the accompanying inflow of highly developed technology and skills. The possible effects of disinvestment can be seen from the several estimates of foreign investment in South Africa. Holman (1985) estimates that in 1983 the value of United Kingdom's direct and indirect investments in South Africa amounted to over R22 billion, representing approximately $40-50 \%$ of total foreign investment in the Republic. Noffke (1984) reports that in 1984 the 350 large United States companies had more than R5,5 billion invested in South Africa. When bank loans and investment in equities are included the total United States investment in South Africa is over R28 billion. The South Africa-German Chamber of Commerce has estimated that West German investment in South Africa in 1985 was worth DM 1,4 billion. These figures suggest that South Africa is highly dependent on foreign investment. Even in the event of a partial disinvestment, a high level of unemployment and a substantial decline in economic growth can be expected.

A recent survey on the effects of trade sanctions on the South African economy was conducted by Nel (1986) for the University of South Africa's Bureau of Market 
Research. This survey was based on a questionnaire to more than 3800 companies employing some $52 \%$ of all employees in South Africa. Nel (1986) has shown that in the event of total trade sanctions against South Africa one million workers will be unemployed. It was also shown that $84 \%$ of the jobs lost would be from the black community. If the existing 1.7 million unemployed blacks are added to those becoming unemployed as a result of sanctions, $31,9 \%$ of all economically active blacks would be out of work. Therefore, total trade sanctions against South Africa will have significant socio-economic consequences. Nel (1986) observes that his findings are contrary to the popular opinion that sanctions will cause a boom resulting from import replacement. It has been suggested that South Africa has already completed all major import replacement projects and that further reductions in imports will require large sums of capital and sophisticated technology, neither of which are readily available in South Africa (Financial Mai1, 1986c).

A recent investigation in the United States by Chase Econometrics has made an in-depth study of the South African economy under three political scenarios - the continuation of the status quo; the emergence of a multiracial coalition government; and a sharp swing to the right. A computer model developed by El-Naggar ${ }^{2}$ under all three scenarios revealed that over the next few years the South African economy would remain ravaged by adverse political and economic considerations, with business opportunities minimal and business confidence weak. The computer analysis also revealed that South Africa would be very vulnerable to international trade sanctions. It was further shown that withdrawal of foreign investment would be detrimental to the South African economy, although the initial impact on employment would be favourable. The El-Naggar economic model point to uneven and sluggish growth no matter what favourable political developments may unfold in South Africa ${ }^{2}$. This suggests that South Africa, which was once a fertile environment for rapid economic growth has now been relegated to Third-World status for at least the next five years.

Another econometric analysis of the effect of trade sanctions on the South African economy has been provided by the Federated Chamber of Industries (FCI). This investigation used a 99-sector input-output matrix under three scenarios - existing and proposed trade measures adopted by South Africa's major trading partners are enforced; increased trade sanctions to include all exports but allowing South Africa to continue exporting by paying a 'sanctions discount'; total mandatory international sanctions which are $80 \%$ effective. The FCI econometric model revealed that under existing trading conditions the Gross Domestic Product (GDP) will decline by $1,7 \%$ in the next two years. The second scenario would result in the GDP declining by $6,7 \%$ in the next two years. The third (worst case) scenario predicts a major slump in the economy in which the GDP is expected to decrease by $29 \%$ in five years. The FCI study concludes that trade sanctions can damage the economy more seriously than generally perceived by observers both inside and outside the country ${ }^{3}$.
Over the past decade or so, South Africa has had to contend with informal sanctions arising from foreign consumer resistance to South African products. Now South Africa faces the prospect of formal international sanctions. Preece (1986) reports that several influential figures in government, the civil service, and the private sector believe that a siege economy could provide an economic boom in South Africa. Their argument is that compulsory import substitution and the 'Buy South African' campaign could provide sufficient economic growth and employment opportunities. They also argue that export earnings could be sufficiently maintained to provide the foreign exchange necessary to secure essential capital goods and oil imports. This analysis is based on the experience of post-UDI Rhodesia which enjoyed considerable economic prosperity despite international sanctions. However, any comparisons between South Africa and Rhodesia are highly misleading because the former is much more industrialized than the latter.

Clarke (1986) reports that the majority opinion of manufacturers is that most economically viable import replacement projects have already been developed in South Africa. Any large scale import substitution would imply investments in projects that are not likely to be economically viable. Furthermore, import substitution would be undertaken only to the extent that spare production capacity exists. There is much scepticism regarding the extent to which local manufacturing companies will be able to make import replacement economically viable. Before such projects are undertaken manufacturers will have to study volume, price requirements and economies of scale. It is generally agreed that manufacturers in the United States, EEC countries and Japan have larger markets for their products and are more price competitive because of economies of scale attained in manufacturing. South Africa has a relatively smaller domestic market and with sanctions precluding foreign markets, the cost of local manufacture is bound to be higher than imported goods. Another disadvantage of import substitution is that the disciplining force of cheaper imports will be lost to local manufacturers. Furthermore, economic sanctions would inevitably delay the introduction of more advanced technology into local manufacturing.

Despite the limitations of import replacements certain sectors of the economy are bound to benefit from sanctions. The chemical, electronics and engineering sectors are frequently cited for their potential for import replacement. This is especially true for those companies that have spare manufacturing facilities as well as strong research and development departments that could provide technical expertise denied by foreign countries. It can be expected that sanctions could stimulate the development of infrastructure in this country. It would be reasonable to assume that the government would take steps to stimulate the economy to replace employment lost through sanctions. With such an eventuality labour intensive building and civil engineering industries could be stimulated. Furthermore, manufacturers and suppliers of raw materials used in infrastructural industries 
are likely to be major short-term beneficiaries of sanctions.

It has been reported (Carte, 1986) that South Africa should have no difficulty in countering the trade ban on mineral exports. This applies especially to high-value and low-volume commodities such as gold, diamonds and platinum. Since these precious metals account for about $70 \%$ of export earnings, it would seem that South Africa's major source of foreign exchange is assured. It also appears that Switzerland holds the key to South Africa continuing exportation of gold (which account for about $50 \%$ of export earnings) in the event of sanctions. About $90 \%$ of South Africa's gold exports are routed through Zurich where the metal is transferred to bonded warehouses. Furthermore, most South African gold is sold through Johannesburg telephones and telexes, so when it arrives in Switzerland it is already owned by nonSouth Africans. The problem of evading sanctions can be eased considerably if just one country refrains from imposing them. Tilston (1986) reports that local exporters are confident that Switzerland will not impose sanctions on South Africa in line with its proclaimed policy of neutrality. This will enable South African businesses to set up fronts in Switzerland to reroute its exports to other countries.

Exporters generally agree that most goods exported in bulk should continue to find access to foreign markets (Southey, 1986). This is because the source of bulk goods is difficult to identify and goods are often mixed with the same exports from other countries at the world's major shipping centres. Furthermore, several export houses specialize in finding markets for minerals. It would seem that minerals such as chromium, manganese, vanadium and titanium which are exported in bulk will continue to find overseas markets, especially if third parties are involved in the transactions. However, easily identifiable exports such as textiles, wines, deciduous and citrus fruits are much more vulnerable to overseas consumer and trade union resistance.

Of particular importance to exporters is the effect of sanctions on foreign exchange earnings. It has been demonstrated that earnings from the export of precious metals are likely to increase in the short term as prices spiral upwards in response to fears of disruption in supplies $^{4}$. The recent sharp increase in the platinum price on rumours of a supply disruption confirms this belief. As South Africa is responsible for about $90 \%$ of the world platinum production it would be virtually impossible to embargo the export of this metal. However, there is a danger that users of platinum would look for cheaper alternatives if the price increases substantially. It can be expected that other strategic minerals (chromium, manganese, vanadium and titanium) would also enjoy a short-term price boom in the event of sanctions. However, this would be followed by a gradual deterioration of these industries as cheaper substitutes are developed and producers from other countries take over markets vacated by South African producers.

It has been reported (Southey, 1986) that there is a certain level of demand for several commodities which cannot in the short term be compensated by increased production by non-South African producers. Some of these commodities are: coal; iron ore; copper; aluminium; wool and mohair. Of all South Africa's minerals and metal exports coal is the most vulnerable to sanctions. Shuttleworth (1986a) reports that satellite tracking could monitor the destination of coal carriers departing the coal terminal at Richards Bay, and assay tests could easily indicate the origin of the coal. The real danger is that Japan and the EEC which purchase over $80 \%$ of Africa's coal exports, are said to be considering an embargo on coal early in 1987 . The coal sector on the JSE has already declined substantially in response to the possibility of such an embargo.

Sanctions against South Africa have become a reality and a further escalation is inevitable. Many South African companies long ago prepared contingency plans to circumvent sanctions. Alternative trade routes and networks and the use of third parties to hide identity have in many cases already been established. Tilston (1986) reports that many companies have removed 'made in South Africa' labels from their goods and are rerouting them through free ports such as Rotterdam and Hamburg. The ease of disguising the origin of goods is illustrated by the failure of the long-standing oil embargo against South Africa. Most shipping agents and cargo carriers have already prepared contingency plans to use alternative trade routes and shift documentation to third countries. It has been reported (Tilston, 1986) that the major South African banks have established financial channels in countries such as Switzerland which they believe will remain open under the severest trade sanctions. The government has also realized the key role it has to play in minimizing the hardships caused by sanctions. To this end it has established a committee in the Department of Trade and Industries to advise and render financial assistance to certain traders confronted with sanctions.

South Africa can take comfort from the fact that trade sanctions did not succeed against Rhodesia or against any other country. However. the relative ease with which sanctions can be overcome should not lull South Africa into a false sense of security. Sanctions are a double-edged sword, hurting those that apply them as much as the victim. South Africa may benefit in the short term by import replacement and perhaps higher export earnings from precious and strategic minerals. However, in the long term factors such as scarcity of capital, technological obsolescence, disadvantages inherent in the lack of international co-operation and competition, and misallocation of resources would indicate that the cost of evading sanctions is too high. Furthermore, the economic stagnation accompanying a siege economy is such that it will take many years to recapture the markets lost through sanctions when the trade embargo is removed. In the mean time, South Africa will have to live with economic and other forms of sanctions until an acceptable political dispensation is established. South African companies should adopt new strategies to minimize the impact of trade sanctions: focus strongly on more sophisticated marketing techniques; use alternative export 
routes; improve the quality of local production and become more competitive in the international market place; and diversification into new markets less vulnerable to sanctions.

\section{The effects of trade sanctions and disinvestment on the Johannesburg Stock Exchange}

The JSE, like any other stock market, mirrors the state of the economy in general, and more specifically, the prospects of individual companies within a particular sector. With regard to sanctions, the different sectors of the JSE will be influenced by the specific impact of sanctions on the prospects of the constituent companies. In recent months coal, manganese, sugar, and iron and steel shares have declined in value, reflecting the adverse effects of sanctions. On the other hand, strategic minerals, gold and platinum shares have recorded massive increases in value to reflect the possibilities of increased earnings in the event of disruption of supplies. Also likely to benefit from sanctions are trade financing and confirming houses which could route exports through overseas branches.

External factors such as the EEC ban on new investments to South Africa is also likely to have some influence on the JSE. The EEC ban on investments has not been precisely defined and it would seem that direct investments and not portfolio investment fall within the ambit of the legislation. In the United States, the House of Representatives passed legislation that would force the delisting of South African companies on American stock exchanges. However, this measure was not included in the Comprehensive Anti-Apartheid Act of 1986. It can be expected that in future both the EEC and the United States are likely to take measures to prohibit portfolio investment in South Africa. Therefore, disinvestment of South African securities is likely to have a major impact on JSE share prices.

Brealey \& Kaplanis (1986) analyzed the effect of a boycott of South African security investments on the welfare of boycotters (foreign investors disinvesting South African securities) and the rest (South African investors and foreigners not party to the boycott). It was demonstrated that an efficient boycott is one that succeeds in imposing a maximum welfare loss on the boycotted at a minimum cost to the boycotter. A boycott of South African securities is unlikely to be implemented by all foreign investors because there is an incentive to free-ride and let the boycotters impose the welfare loss on themselves. Those foreign investors that are not party to the boycott are therefore in the same position as South African investors who are boycotted. In order to measure the effect of a boycott of South African securities, a model of linear taxes on international investment (developed by Kaplanis, (1985)) is used. This model assumes that the tax rate is sufficiently large so as to eliminate all foreign security investment in South Africa which is subject to this tax.

Brealey \& Kaplanis (1986) demonstrate that in the absence of any barriers to investment in South Africa, both South African and foreign investors will maximize their wealth by holding market portfolios. A boycott of South African securities will result in a restructuring of portfolio holdings - South African investors increasing their exposure to local securities and foreign investors increasing their exposure in non-South African (foreign) securities. The welfare effects of a boycott of South African securities has twofold consequences. First, there is a loss of diversification resulting from the elimination of South African securities from the universe of investment alternatives. Second, there is a one-time change in security prices caused by selling South African securities and replacing them with other securities.

The welfare model developed by Brealey \& Kaplanis demonstrates that a boycott of South African securities will reduce the welfare of both South African and foreign investors. It is further shown that the loss of diversification is shared evenly between the two groups of investors only if they are equally wealthy. In the event South African investors are less wealthy than foreign investors, the former will suffer a proportionately larger welfare loss. In the absence of exchange control, it can be expected that South African investors would hold internationally diversified portfolios to derive the advantages of geographical diversification. A boycott of South African securities is likely to result in local investors being obliged to acquire South African securities disinvested by foreigners. Therefore, South African investors are not likely to attain efficient (optimal) portfolios because of a larger holding of South African securities and a corresponding smaller holding of foreign securities. Furthermore, it can be expected that South Africa may retaliate by forbidding its residents from acquiring foreign securities, resulting in their inability to construct optimally diversified portfolios. Thus, even with the absence of exchange control, South African investors can be expected to suffer a loss in diversification as a result of a boycott of South African securities.

At present, South African investors are subject to exchange control regulations, and are therefore confined to holding South African securities. A portfolio of South African securities cannot be regarded as efficient as foreign securities are excluded from the universe of available securities. In the event of a boycott of South African securities, investors in this country will have to take up all South African securities sold by foreign investors. However, the loss in welfare will be smaller than in the case where no exchange control existed. Because of exchange control there will be no change in the geographical composition of South African portfolios. Except for investments in De Beers and Sasol, foreign portfolio investors do not make any meaningful investment in South African industrial securities. Foreign investors are mainly interested in goldmining and strategic minerals equity shares of South Africa. A report by JSE brokers (Davis Horkum Hare, 1985) revealed that on 30 June 1985 foreign shareholders held about $29 \%$ of the market capitalization of all South African mining shares. Therefore, in the event of a boycott of South African securities, local investors would be obliged to acquire the 
predominantly goldmining and minerals related shares disinvested by foreign investors. Several industrial companies such as Barlows, Metal Box, AECI, and SAB have their shares listed on overseas exchanges and it can be expected that they would suffer the same fate as goldmining shares.

A boycott of South African securities can be expected to have a significant effect on the portfolio composition of institutional investors in South Africa. The shares disinvested by foreign investors are unlikely to be evenly distributed among all categories of South African investors. The institutional investors in foreign countries generally invest in high quality (expensive) South African goldmining and mining house shares. In the event of disinvestment it is unlikely that individual investors in South Africa would be in a position to acquire any meaningful quantities of high quality goldmining shares released by foreign investors. Therefore local institutional investors can be expected to increase their exposure to South African mining shares by taking advantage of a fall in prices in the event of disinvestment. The institutional investors would improve the portfolio returns but would incur much higher risks associated with goldmining shares. Institutional investors, such as unit trusts, may face additional problems related to the restrictions on the maximum percentage of their funds that can be invested in specific securities or certain categories of investment. In general, South African investors are likely to have their wealth reduced by a loss of diversification caused by holding a larger proportion of goldmining shares which cannot be considered optimal in terms of efficient portfolios. There is also the added cost of restructuring a portfolio that is inevitable as a result of foreign investors releasing large parcels of South African securities.

In the absence of any boycott of South African securities, foreign investors can be expected to hold a world market (international) portfolio. In the event of a disinvestment of South African securities, the forced sale will cause the relative prices of South African and foreign securities to change. Brealey \& Kaplanis (1986) have shown that a tax on South African securities induces an increase in the return on foreign assets relative to South African assets. Foreign investors participating in the boycott would be obliged to sell their South African securities at prices below their current equilibrium levels. Furthermore, foreign investors will have to substitute more expensive foreign securities to replace the South African securities. Therefore, the welfare of the boycotting foreign investors is further diminished by price changes associated with a forced sale of South African securities.

Bhana (1986) has shown that South African goldmining shares are unique in their ability to possess counter cyclical movements in relation to the major foreign stock exchanges. Therefore, as South African goldmining shares are eliminated from the investment universe it will become increasingly difficult for foreign investors to construct optimally diversified portfolios. There is the possibility of foreign investors acquiring gold shares in countries such as Australia, United States, and Canada. However, none of these countries are able to offer returns comparable to high quality South African goldmining shares (Ryan, 1985). In addition, foreign goldmining shares have an insignificant market capitalization in comparison with their South African counterparts.

As a result of pressure from various activist groups, several institutional investors in the United States have shown a strong desire to seek alternatives to South African goldmining shares. Chambliss (1985) reports that in response to this, the Precious Metals Inc. in the United States has launched a closed-end gold investment fund that will not hold any shares or gold bullion originating from South Africa. It is further reported that although the 300 million dollar gold investment fund has been well received on the NYSE, it is unlikely to provide any serious competition to South African goldmining shares.

For the South African investor, the diversification and the price effect work in opposite directions. It has already been shown that South African investors will have their diversification eroded by a change in composition of South African securities acquired from foreign investors. However, a South African investor can be expected to benefit from foreign sales of South African securities. Since South African investors are already holding optimal portfolios (as determined by exchange control), they are unlikely to acquire large quantitites of additional securities unless the price of these securities are lowered. Furthermore, the fall in the price of securities must more than compensate for the perceived loss of diversification. Therefore, South African investors must always benefit as a result of a disinvestment by foreign investors. This analysis suggests that a disinvestment of South African securities is likely to be ineffective because only foreign investors are likely to suffer a loss in welfare. Furthermore, foreign investors are unlikely to agree to sustaining a welfare loss which at the same time enriches South African investors.

A limitation of the Brealey and Kaplanis model is that a boycott of South African securities is the only friction to international capital movement i.e. the analysis is limited to investment in financial assets. However, it is unlikely that the disinvestment lobby would be satisfied with a mere disinvestment of South African securities. Foreign multinational companies are very visible by their presence in South Africa and are more vulnerable to pressure exerted by activist groups than foreign portfolio managers. Therefore, a trade boycott and a withdrawal of foreign multinational companies can be expected to accompany a disinvestment of South African securities. While a boycott of South African securities has not yet been implemented, multinational companies have already begun to withdraw in response to political pressure and government legislation.

The current withdrawal of multinational companies is accompanied by management buy-outs or sale to South African investors. The Anti-Apartheid Movement and other pressure groups have raised objections to the local purchase of foreign multinationals businesses in South 
Africa. The objection is that buy-outs benefit South Africa because foreign assets are purchased at bargain prices and the new owners continue to receive products and technology previously provided by the multinationals. Therefore, it is conceivable that the political activist groups will apply pressure to legislators to prevent the flow of goods, services and technology to the new local owners. Furthermore, if there is a mass withdrawal by multinational companies, domestic confidence will be low and local buy-outs may not take place. An escalation of a boycott of South Africa can therefore be expected to slowdown economic growth and cause much hardships such as rising unemployment and scarcities of essential goods and services. Therefore, in the long term an extended boycott is likely to cause a major decline in share prices on the JSE.

The United States has the largest portfolio investment in South Africa, accounting for over $56 \%$ of mining shares and about $68 \%$ of goldmining shares held by foreign investors (Davis Borkum Hare, 1985). The majority of United States investors prefer to acquire South African shares through American Depository Receipts (ADR's). Furthermore, an increasing volume of European investments in South African mining shares are taking place in ADR form. The Comprehensive Anti-Apartheid Act of 1986 has provided a further disincentive for United States investors making portfolio investment in South Africa. In terms of this Act no South African share listings or additional share issues by a company having ADR status will be available in ADR form. As a result, United States investors will have to deal directly (Johannesburg or London) for all shares listed after 2nd October 1986. Furthermore, the 'pre-release' system whereby the ADR banks in New York issued ADRs for South African shares without having confirmation that the Johannesburg scrip has been placed with a South African bank has been terminated. Shuttleworth (1986b) is of the opinion that these new developments are intended to discourage ownership of South African equities by foreign investors. These developments are likely to increase the prospects of foreign disinvestment of South African share portfolios.

The disinvestment of South African securities by foreign investors and the corresponding enlarged security holdings by local institutional investors is likely to have far reaching consequences for the South African economy. The increased size of the institutional portfolio holdings in industrial companies is likely to contribute towards a change in control and structure of many South African companies. For instance, the recent disinvestment of Premier Milling has resulted in a change in ownership and the restructuring of the food industry in which the resultant Premier Milling/SAB group of companies operate. This restructuring has enabled the SAB/ Premier Milling group to have a monopolistic/ oligopolistic control over several industries in which they operate. The SAB/Premier Milling group is in turn controlled by the Anglo American Corporation (AAC). The $A A C$ and its subsidiaries constitute the largest group of companies listed on the JSE. It is extremely unlikely that companies in the SAB/Premier Milling group will encounter any new major competitors in those industries in which they have gained market control as this will entail confrontation with the largest conglomerate in South Africa.

The foreign disinvestment of shares in Rennies has resulted in a restructuring and increased economic concentration in the shipping and hotel industries. The decision by Coca-Cola to sell its remaining equity investment in South Africa has resulted in the SAB group of companies entrenching their existing dominant position in the beer and beverages industries in South Africa. Furthermore, Barclays PLC in the United Kingdom has decided to sell its $40 \%$ equity stake in Barclays National of South Africa to the existing major shareholders in the AAC group. This will enable the AAC group of companies to play a dominant role in the banking industry in South Africa. Furthermore, Liberty Life is currently holding a $22 \%$ equity stake in Standard Bank Investment Corporation (SBIC). If the London parent company Standard Charter is forced to sell its South African interests it can be expected that Liberty Life will be the major shareholder in SBIC. The control of the two largest banks in South Africa by conglomerates will inevitably lead to restructuring and further economic concentration in the banking industry. Further restructuring and increased economic concentration in South Africa can be expected as companies such as IBM, Kodak, General Motors and General Electric have already decided to sell off their stake in this country.

The conglomerate companies in South Africa are already in possession of an inordinately large share of the South African economy. The process of disinvestment of South African industrial companies is likely to result in a further increase in asset concentration in the hands of the conglomerates. A natural consequence of the domination of the South African economy by a few conglomerates is the large number of price cartels and monopolies/oligopolies in this country. The lack of competition and price cartels in industries such as newspapers, milk, paint, cement, cigarettes, and building materials has resulted in the price of goods and services being unrelated to the prevailing supply and demand characteristics in these industries.

It has been reported (Financial Mail, 1986a) that the high rate of inflation currently prevailing in South Africa is to a large extent influenced by the high level of economic concentration. The seriousness of economic concentration in South Africa can be reflected by the recent amendment to the Maintenance and Promotion of Competition Act of 1979, and has resulted in all forms of resale price maintenance, horizontal price collusion and collusion of market sharing that is against the public interest being outlawed after 2 May 1986 (unless the Minister of Trade and Industries grants an exemption). There is a tendency to measure the harmful effects of disinvestment in terms of unemployment and slowdown in economic growth. Due consideration should also be 
given to the likelihood of disinvestment having an adverse effect on the long-term viability of the free enterprise system in South Africa.

\section{Conclusion}

The relative ease with which sanctions can be overcome should not lull South Africa into a false sense of security. South Africa may benefit in the short term by import replacement and perhaps higher export earnings from precious and strategic minerals. However, up to one million workers may be unemployed in the event of total trade sanctions. It appears that prospects for growth through import replacement are exaggerated. South Africa has already completed all major import replacement projects and further reductions in imports will require large sums of capital and sophisticated technology, neither of which are readily available. Furthermore, import replacement is likely to result in a price increase and a reduction in the quality of manufactured goods. The longterm effects of sanctions such as: scarcity of capital; technological obsolescence; disadvantages inherent in the lack of international co-operation and competition; and misallocation of resources will harm the economy. This would suggest that South Africa will have to bear severe hardships in the event of total trade sanctions being implemented.

Precious metals and strategic minerals should have no difficulty in evading trade sanctions and goods exported in bulk are also likely to continue finding foreign markets. Since precious metals account for about $70 \%$ of export earnings a sufficient level of foreign exchange would be available to purchase oil and other strategic imports. Earnings from the export of precious metals and strategic minerals are likely to increase in the short term in response to fears of disruption in supplies. In the long term earnings may decline as cheaper substitutes are developed and markets are lost to foreign producers.

Local investors are expected to benefit from foreign disinvestment of South African equity shares. The fall in price of the securities so acquired should more than compensate the possible loss of diversification in portfolio holdings. The high quality (expensive) mining shares disinvested by foreign investors is likely to result in local institutional investors increasing their exposure to goldmining shares. The increase in size of institutional portfolio holdings in industrial companies is likely to contribute towards a change in control and structure of many South African companies. A greater tendency towards monopolies and oligopolies could have a detrimental effect on the free enterprise system in South Africa.

\section{Notes}

1. R. Knight, quoted in 'US-SA Disinvestment - Ethical Search'. Financial Mail, vol. 101, 29 August 1986.

2. H. El-Naggar, quoted in 'Sanctions - gloomy US view', Financial Mail, vol. 101. 8 August 1986.

3. Federated Chamber of Industries, quoted in 'The Sanctions Crunch', Financial Mail, vol. 102, 28 Novem- ber 1986.

4. A. Edwards, quoted in 'Mixed bag for Minerals', Financial Mail, vol. 100, 27 June 1986.

\section{References}

Bhana, N. 1986. International share portfolio diversification: possible benefits for South African investors. S. Afr. J. Bus. Mgmnt., vol. 17, 162-108.

Brealey, R.A. \& Kaplanis, E.C. 1986. The Welfare Effects of Sanctions on Portfolio Investment in South Africa. Unpublished manuscript, University of London, IOp.

Carte, D. 1986. Sanctions - two edges to the sword. Bus. Times, 13 July, 1.

Chambliss, L. 1985. U.S. Funds shuns SA as disinvestment pressure rises. Bus. Times, 27 January, 4.

Clarke, K. 1986. Sanctions - who will benefit. Fin. Mail, vol. $102,84$.

Davis Borkum Hare Mining Research. 1983. Foreign Holdings in South African Mining Shares as at June 30, 1983. Unpublished Research Manuscript, Johannesburg.

Davis Borkum Hare Economic Research. 1985. Foreign Holdings in South African Mining Shares as at December 1984/June 1985. Unpublished Research Manuscript, Johannesburg.

Financial Mail. 1986a. Restrictive trading - The breakers are here. Vol, 100, 18 April, 36-38.

Financial Mail. 1986b. US sanctions - call off the dogs. Vol. 102, 31 October, 29-31.

Financial Mail. 1986c. Inviolate to sanctions? Vol. 102, 5 December, 57-60.

Holman, M. 1985. Sanctions: UK has most to lose. The Star. 10 August 1985, 16.

Kaplanis, E.C. 1985. International Structure of Security Prices. Unpublished $\mathrm{PhD}$ thesis, University of London.

Koenderman, T. 1985. Sanctions - real threat or myth? Leadership S. Afr., vol. 4, 21-33.

Malan, T. 1981. South Africa and economic sanctions. Africa Insight, vol. 11, 4-9.

Nel, P.A. 1986. An Assessment of the Development and Welfare of Employees in the Republic of South Africa. Research Report No. 133. Bureau of Market Research, University of South Africa.

Nöffke, C. 1984. Growing Disinvestment Campaign Tip of Iceberg. South Africa Forum, vol. 7, 1-12.

Northedge, R. 1986. Barclays is not off hook. Sunday Times, 30 November, 34.

Preece, H. 1986. Living with sanctions. Finance Week, vol. 29, 669-674.

Ryan, C. 1985. Gold/Platinum shares running. Financial Mail, vol. 101,93 .

Shuttleworth, G. 1986a. Coal dominoes - strong plea to the US Senate. Finance Week, vol. 30, 284-285.

Shuttleworth, G. 1986b. ADR hassles. Finance Week, vol. 31, 449.

Southey, D. 1986. SA waiting for the sanctions blade to drop. Bus. Times, 15 June, 5.

Spandau, A. 1979. Economic Boycott Against South Africa Normative and Factual Issues. Cape Town: Juta and Company Limited. 
Spicer, M. 1985. Stick 'em up - US points six shooter at SA policies. Finance Week, vol. 24, 341-343.

The Economist 1985a. Cry, the unbeloved country. Vol. 294, 43-44.

The Economist. 1985b. Johannesburg stockmarket - out of sorts, not out of bounds. Vol. 294, 84 .

The Economist. 1985c. Foreign firms trickle out. Vol. 296 74.

Tilston, J. 1986. Behind closed doors. Finance Week, vol. 30. 341-344 